\title{
APLIKASI ATURKOST BERBASIS WEB UNTUK PENGELOLA DAN PENGHUNI KOST (STUDI KASUS: KOST JURA)
}

\section{WEB-BASED ATURKOST APPLICATION FOR MANAGEMENT AND TENANT OF BOARDING HOUSE (STUDY CASE: KOST JURA)}

\author{
Steven $^{1)^{*}}$, Kevin Christianto ${ }^{2)}$ \\ ${ }^{1,2)}$ Program Studi Sistem Informasi, Universitas Bunda Mulia
}

Diterima 24 Agustus 2021 / Disetujui 30 Agustus 2021

\begin{abstract}
Boarding house is a service that offers a room to live with a certain number of payments for each month. The boarding house tenants also have difficulty in informing the boarding house manager about their problems. The management system "AturKost" is designed to overcome these problems by helping boarding house manager to manage boarding houses. "AturKost" is designed to be accessed real-time by manager and tenants of the boarding house so they get accurate information related to operations that occur in the boarding house. The management system "AturKost" is expected to facilitate the interaction between the manager and the tenants. The method used to design the management system "AturKost" is System Development Life (SDLC) with a waterfall model. SDLC serves to describe the main stages and the steps of each stage which are divided into five main activities and they are analysis, design, implementation, testing, and maintenance. In the waterfall model, system design will be easier to control and can be scheduled properly because the design is carried out in stages from analysis to maintenance. The results obtained from the design of the "AturKost" management system is this system can facilitate every recording of activities that occur in the boarding house. The boarding house manager can also view tenant data, complaints, requests for additional services, and payments made to the boarding house. "AturKost" is also made simply by displaying only the necessary functions. The tenants can also easily interact with the manager by using the available functions.
\end{abstract}

Keywords: System Design, Boarding House System, PHP, SDLC, Waterfall, IS

\begin{abstract}
ABSTRAK
Indekos atau kost adalah sebuah jasa yang menawarkan sebuah kamar atau tempat untuk ditinggali dengan sejumlah pembayaran tertentu untuk setiap periode tertentu (umumnya pembayaran per bulan). Penghuni kost sering kesulitan dalam menginformasikan kendalanya kepada pengelola kost. Sistem manajemen "AturKost" dirancang untuk mengatasi permasalahan tersebut dengan membantu pemilik kost untuk lebih baik lagi dalam mengelola gedung kost. Sistem "AturKost" juga dirancang untuk dapat diakses secara real-time oleh pengelola dan penghuni kost sehingga mendapatkan informasi yang akurat terkait operasional yang terjadi di gedung kost. Sistem manajemen "AturKost" diharapkan dapat memudahkan interaksi antara pengelola kost dengan penghuni kost. Metode yang digunakan dalam perancangan sistem manajemen "AturKost" adalah System Development Life (SDLC) dengan siklus pengembangan sistem waterfall. SDLC berfungsi untuk menggambarkan tahapan-tahapan utama dan langkah-langkah dari setiap tahapan yang secara garis besar terbagi dalam lima kegiatan utama yaitu analisis, desain, implementasi, pengujian, dan pemeliharaan. Pada siklus waterfall, perancangan sistem akan lebih mudah dikontrol dan dapat dijadwalkan dengan baik karena perancangan dilakukan secara bertahap mulai dari analisis hingga pemeliharaan. Hasil yang didapatkan dari perancangan sistem manajemen "AturKost" adalah sistem ini dapat memfasilitasi setiap pencatatan aktifitas yang terjadi pada gedung kost. Pengelola kost juga dapat melihat data penghuni, komplain, permintaan layanan tambahan, dan pembayaran yang terjadi pada gedung kost. Sistem manajemen "AturKost" juga dibuat secara sederhana dengan hanya menampilkan fungsi-fungsi yang diperlukan saja. Penghuni kost juga dapat dengan mudah berinteraksi dengan pengelola kost dengan menggunakan fungsifungsi yang tersedia.
\end{abstract}

Kata Kunci: Perancangan Sistem, Sistem Kost, PHP, SDLC, Model Waterfall, SI.

*)Korespondensi Penulis :

stevenjaster@gmail.com 


\section{PENDAHULUAN}

Indekos atau kost adalah sebuah jasa yang menawarkan sebuah kamar atau tempat untuk ditinggali dengan sejumlah pembayaran tertentu untuk setiap periode tertentu (umumnya pembayaran per bulan). Pemilik kost menyediakan sebuah bangunan dengan banyak kamar untuk dihuni oleh orang yang membutuhkannya (Bilqis, 2018). Setiap pemilik kost memiliki gaya pengelolaan yang berbeda-beda. Hal ini menyebabkan keluhan dari penghuni kost seperti pendingin yang rusak, kamar mandi yang bocor, dan lainnya. Pemilik kost juga terkadang mengalami kesulitan dalam menagihkan biaya sewa kepada penghuni dan mengatur daftar penghuni yang masuk dan keluar. Untuk melakukan pengelolaan kost yang baik diperlukan sebuah sistem yang dapat memantau setiap aktifitas yang terjadi di dalam operasional kost. Saat ini pengelolaan kost banyak dilakukan menggunakan sistem pencatatan manual seperti menulis data penghuni, laporan pembayaran, keluhan pada sebuah buku maupun menggunakan excel. Sistem yang digunakan sebelumnya dapat dikembangkan menggunakan sistem berbasis website dimana sistem ini akan mencatatkan setiap aktifitas di gedung kost dan dapat diakses langsung oleh pemilik kost selama memiliki koneksi internet. Pemanfaatan teknologi dan informasi dalam pengembangan suatu bisnis sangat diperlukan agar pemilik rumah kost dapat bertahan dan berkembang menjadi lebih baik (Syam, 2018). Sistem manajemen "AturKost" yang dirancang ini akan memudahkan pemilik kost untuk mengetahui kondisi gedung kost mulai dari data diri penghuni, laporan pembayaran, keluhan dan permintaan tambahan yang disampaikan oleh penghuni. Sistem ini akan mencatat setiap aktifitas yang terjadi di gedung kost secara real-time sehingga pengelola kost dapat langsung bertindak untuk menyelesaikan masalah yang timbul.

Sesuai latar belakang yang telah dikemukakan sebelumnya, maka rumusan masalah dari penelitian ini adalah:

1. Bagaimana cara mencatatkan aktifitas gedung kost dan melaporkannya kepada pengelola kost secara real-time?
2. Bagaimana rancangan sistem manajemen kost yang mudah digunakan oleh pemilik kost?

3. Bagaimana cara penghuni kost untuk berinteraksi dengan pengelola kost melalui sistem manajemen kost?

Pembatasan suatu masalah digunakan untuk menghindari adanya penyimpangan maupun pelebaran pokok masalah agar penelitian tersebut lebih terarah dan memudahkan dalam pembahasan sehingga tujuan penelitian akan tercapai. Beberapa batasan masalah dalam penelitian ini adalah sebagai berikut:

1. Sistem "AturKost" akan dirancang menggunakan bahasa pemrograman php versi 8.0.3 dengan database phpMyAdmin versi 5.1.0. Framework yang digunakan adalah CodeIgniter versi 4.1.1.

2. Sistem "AturKost" yang dirancang menggunakan platform Website agar mudah diakses oleh penjaga kost dan pemilik kost.

3. Sistem "AturKost" yang dirancang akan berfokus pada kebutuhan internal pengelolaan kost sesuai dengan hasil wawancara. Sistem "AturKost" yang dirancang akan berfokus pada:

- Aktifitas pengisian data diri penghuni.

- Laporan pembayaran penghuni kost.

- Pencatatan keluhan penghuni dan tindak lanjutnya.

- Kebutuhan lainnya yang diketahui dari hasil wawancara dengan pemilik kost.

Adapun tujuan dan manfaat dari penelitian ini adalah:

1. Untuk merancang sistem informasi yang dapat membantu pengelola kost untuk lebih baik lagi dalam mengelola gedung kost.

2. Untuk merancang sistem informasi yang dapat diakses secara real-time oleh pengelola dan penghuni kost sehingga mendapatkan informasi yang akurat terkait operasional yang terjadi di gedung kost.

3. Untuk merancang sistem informasi yang memudahkan interaksi antara penghuni kost dengan pengelola kost. 


\section{TINJAUAN PUSTAKA}

\section{a) Perancangan Sistem Informasi}

Menurut Irawan (2017) perancangan sistem informasi adalah suatu kegiatan di dalam menciptakan suatu konsep kerja terpadu antara manusia dengan mesin yang dihimpun menjadi satu untuk maksud dan tujuan tertentu atau bersama guna menghasilkan informasi yang akurat untuk proses pengambilan keputusan di dalam mendukung fungsi operasi manajemen di suatu organisasi. Suatu kegiatan didalam menciptakan suatu kondisi baru atau solusi yang didasari atas evaluasi dari konsepsi yang serasi serta bentuk permasalahan atau kasus yang ada. Berdasarkan pendapat diatas dapat ditarik kesimpulan bahwa tujuan dari perancangan sistem informasi adalah untuk membantu manajemen organisasi dalam mengambil keputusan dan membantu menghasilkan informasi yang akurat.

\section{b) Data Base Management System (DBMS)}

Menurut Budio (2019) Data Base Management System (DBMS) adalah suatu sistem yang terdiri atas basis data dan perangkat lunak yang bertujuan untuk efektivitas dan efisiensi dalam pengelolaan basis data. DBMS ini menjadi lapisan yang menghubungkan basis data dengan program aplikasi untuk memastikan bahwa basis data tetap terorganisir secara konsisten dan dapat diakses dengan mudah. Efisiensi database adalah sebuah struktur yang dibangun untuk keperluan penyimpanan data. DMBS juga yang berperan untuk membangun struktur tersebut.

\section{c) MySQL}

Menurut Risdiansyah (2017), MySQL (My Structured Query Language) merupakan database server yang bersifat multiuser dan multi-threaded. MySQL didistribusikan secara gratis dibawah lisensi GPL (General Public License). MySQL merupakan turunan salah satu konsep dalam database sejak lama, yaitu SQL (Structured Query Language).

SQL adalah sebuah konsep pengoperasian database, terutama untuk pemilihan atau seleksi dan pemasukan data, yang memungkinkan pengoperasian data dikerjakan dengan mudah secara otomatis. Sebagai database server, MySQL dapat dikatakan lebih unggul dibandingkan database server lainnya dalam query data. Hal ini terbukti untuk query yang dilakukan oleh single user, kecepatan query MySQL bisa sepuluh kali lebih cepat dari PostGreSQL dan lima kali lebih cepat dibandingkan Interbase.

\section{d) PhpMyAdmin}

Menurut Wijianto (2018), PhpMyAdmin adalah aplikasi web yang dibuat oleh phpmyadmin.net dan digunakan untuk administrasi database MySQL. PhpMyAdmin mendukung berbagai operasi MySQL seperti mengelola basis data, tabel-tabel, bidang (fields), relasi (relations), indeks, pengguna (users), perijinan (permissions), dan lain-lain. PhpMyAdmin membantu seseorang untuk membaut database dan tabel, mengisi data, dan lainnya dengan mudah tanpa harus menghafal baris perintahnya.

\section{e) System Development Life Cycle (SDLC) \\ Menurut Asmanto (2020), System} Development Life Cycle (SDLC) merupakan suatu proses pembuatan dan pengubahan sistem serta model dan metodologi yang digunakan untuk mengembangkan sebuah sistem. SDLC adalah kerangka kerja (framework) yang terstruktur yang berisi proses-proses sekuensial dimana sistem informasi dikembangkan. Menurut Mohamat Setiawan (2013) langkah-langkah SDLC terbagi menjadi empat yaitu perencanaan, analisis, desain, dan implementasi.

\section{f) Waterfall Model}

Menurut Yulianto (2018) model waterfall adalah model yang bersifat linear dari tahap perencanaan sampai tahap pemeliharaan. Tahapan berikutnya tidak akan dilakukan sebelum tahapan sebelumnya selesai, dan tidak bisa kembali ke tahap sebelumnya. Menurut Sukamto (2016) model waterfall adalah model menyediakan pendekatan alur hidup perangkat lunak secara sekuensial atau terurut dimulai dari analisis, desain, pengodean, dan pengujian.

\section{g) Php: Hypertext Preprocessor}

Menurut Firman (2016), "PHP adalah skrip bersifat server - side yang ditambahkan kedalam HTML". Server akan bekerja apabila 
ada permintaan dari client. Dalam hal ini client menggunakan kode-kode PHP untuk mengirim permintaan ke server.

Bahasa pemrograman yang banyak dipakai untuk membuat situs web karena gratis, open source, dan berguna dalam merancang aplikasi web. PHP merupakan bahasa scripting server side, dimana pemrosesan datanya dilakukan pada sisi server sehingga server yang akan menerjemahkan skrip program dan hasilnya akan dikirim kepada client yang melakukan permintaan.

\section{h) Unified Modelling Language (UML)}

Menurut Hendini (2016), UML
merupakan metodologi dalam mengembangkan sistem berorientasi objek dan juga merupakan alat untuk mendukung pengembangan sistem.Penggunaan model ini bertujuan untuk mengidentifikasikan bagianbagian yang termasuk dalam lingkup sistem yang dibahas dan bagaimana hubungan antara sistem dengan subsistem maupun sistem lain diluarnya. Tujuan dan fungsi dari penggunaan UML adalah sebagai berikut:

1. Memberikan bahasa permodelan visual kepada pengguna dari berbagai macam pemrograman.

2. Menyatukan praktik-praktik terbaik yang ada dalam permodelan.

3. Memberikan model yang siap untuk digunakan dengan menyediakan bahasa permodelan visual yang ekspresif untuk mengembangkan sistem.

4. Memberikan gambaran rancangan secara detil dan lengkap.

5. Menciptakan bahasa permodelan yang nantinya dapat dipergunakan oleh manusia maupun mesin.

\section{METODE PENELITIAN}

\section{a) Analisis Proses Bisnis}

Proses bisnis kost terjadi antara dua pihak yaitu pihak pemilik kost dan juga penghuni kost. Pemilik kost biasanya menunjuk seseorang atau lebih untuk mengelola gedung kost dan menjalankan operasionalnya. Penghuni kost akan melakukan survey untuk melihat kondisi gedung kost dan kamar yang akan dihuninya. Setelah penghuni kost merasa cocok dengan kualitas dan harga sewa kost, penghuni kost akan menentukan waktu masuk atau check-in.

Penghuni kost selanjutnya akan banyak berinteraksi dengan pihak pengelola kost terkait dengan kendala yang terjadi selama tinggal di kost. Penghuni kost akan menyampaikan keluhan kepada pengelola kost dimana pengelola kost harus bertindak cepat untuk menindaklanjuti komplain tersebut agar reputasi gedung kost tetap terjaga. Saat ini komplain dari penghuni kost banyak disampaikan melalui pesan Whatsapp dan juga penyampaian langsung kepada pengelola secara lisan.

Hal yang sama juga terjadi untuk permintaan tambahan terkait fasilitas kamar. Penghuni kost akan melakukan penambahan fasilitas yang belum tersedia sejak awal seperti televisi, AC, pemanas air, dan sebagainya. Penghuni kost akan menginformasikan kepada pengelola kost permintaan tambahan tersebut dan pengelola kost akan memberikan harga tambahan. Setelah penghuni kost setuju, pihak pengelola kost akan menambahkan fasilitas tersebut untuk penghuni kost.

Proses pembayaran sewa kost dilakukan sebulan sekali dimana selalu ada tanggal jatuh tempo bagi penghuni kost untuk melakukan pembayaran. Pembayaran dilakukan secara langsung maupun transfer ke rekening pemilik kost, namun pembayaran secara langsung berpotensi untuk terjadi penyelewengan uang sewa kost. Pembayaran yang dilakukan biasanya untuk periode tinggal selama satu bulan terhitung dari tanggal masuk.

\section{b) Metode Pengumpulan Data}

Dalam penelitian ini diperlukan objek dan subjek yang harus diteliti sehingga permasalahan yang ada dapat terpecahkan. Metode yang digunakan untuk mengumpulkan data adalah dengan wawancara. Wawancara merupakan proses pengumpulan data, menggunakan informan yang menjawab pertanyaan yang diajukan untuk kepentingan penelitian. Wawancara akan dilakukan kepada beberapa pemilik kost untuk mengetahui apa saja yang dibutuhkan pemilik kost dan dapat diterapkan pada sistem "AturKost"

Wawancara dilakukan dengan 2 orang pemilik kost, Pak Randi sebagai pemilik Kost Jura Cakung dan juga Bu Yurike sebagai pemilik Kost Dwiwarna Mangga Besar. Pak Randi sebagai pemilik Kost Jura Cakung 
menyebutkan saat ini beliau mengelola kostnya dengan cara pencatatan manual. Pencatatan pembayaran saat ini dilakukan menggunakan buku tulis. Untuk status hunian kamar saat ini tidak dicatat, hanya berdasarkan ingatan penjaga kost. $\mathrm{Bu}$ Yurike juga melakukan pencatatan manual untuk Kost Dwiwarna Mangga Besar. $\mathrm{Bu}$ Yurike melakukan pencatatan manual untuk laporan pembayaran dan daftar penghuni beserta nomor kamarnya.

Berdasarkan hasil wawancara, didapatkan kesimpulan tentang sistem manajemen kost yang mereka butuhkan. Pak Randi membutuhkan sistem yang dapat mencatat setiap pembayaran yang dilakukan oleh penghuni kost, mencatat data diri penghuni, tanggal masuk dan keluar kost, dan harga sewa masing-masing penghuni. $\mathrm{Bu}$ Yurike membutuhkan sistem yang lebih lengkap lagi dimana beliau juga membutuhkan status hunian kamar dan daftar keluhan yang disampaikan pelanggan untuk dapat meningkatkan kualitas kostnya.

\section{c) Metode Perancangan}

Metode perancangan sistem adalah metode atau prosedur yang akan digunakan untuk mengembangkan suatu sistem informasi. Penelitian ini fokus untuk menciptakan sebuah sistem manajemen kost dan menggantikan sistem manajemen kost manual. Metode yang digunakan dalam perancangan sistem manajemen "AturKost" adalah SDLC (System Development Life Cycle) dengan siklus pengembangan sistem waterfall. SDLC berfungsi untuk menggambarkan tahapantahapan utama dan langkah-langkah dari setiap tahapan yang secara garis besar terbagi dalam lima kegiatan utama yaitu: analisis, desain, implementasi, pengujian, dan pemeliharaan. Pada siklus waterfall, perancangan sistem akan lebih mudah dikontrol dan dapat dijadwalkan dengan baik karena perancangan dilakukan secara bertahap mulai dari analisis hingga pemeliharaan.

\section{d) Analisis Pengguna dan Fungsionalitas}

Dalam sistem ini akan terdapat dua pengguna pada prakteknya. Pengguna pertama adalah pengelola kost, dalam hal ini termasuk pemilik gedung kost. Pengelola kost dapat melihat data diri penghuni, melihat laporan pembayaran sewa kost, melihat keluhan yang disampaikan penghuni, dan kondisi kamar yang terisi oleh penghuni. Pengguna kedua merupakan penghuni kost yang dapat melihat tagihan pembayaran, meminta layanan tambahan, dan juga menyampaikan keluhan kepada pengelola kost.

Pada sistem ini akan terdapat perbedaan cara mengakses bagi pengguna. Akses dapat dilakukan dengan menggunakan web browser oleh pengelola kost maupun penghuni kost, yang membedakan adalah halaman login dan username yang digunakan oleh pengguna. Akses menggunakan web browser ini sangat memudahkan pengguna karena dapat dibuka melalui desktop, tablet, dan juga smartphone.

\section{HASIL DAN PEMBAHASAN}

\section{a) Flowchart}

Flowchart digunakan untuk menunjukkan urutan-urutan pada sistem manajemen "AturKost". Aktor atau pengguna sistem manajemen "AturKost" adalah pemilik kost, pengelola kost dan penghuni kost. Flowchart sistem manajemen kost dapat dilihat pada gambar berikut:

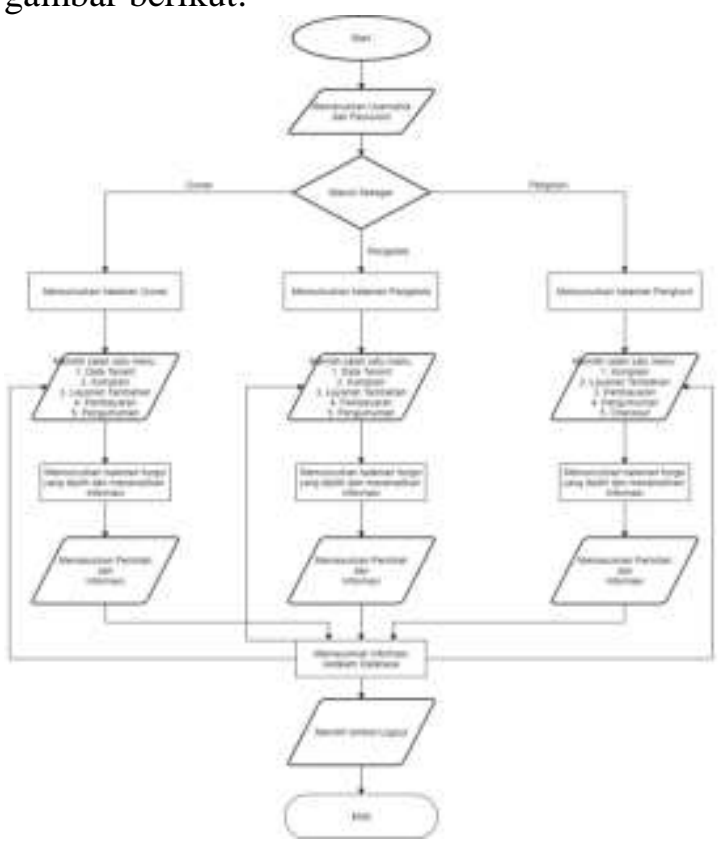

Gambar 1. Flowchart

Pada gambar 1 dapat dilihat alur sistem manajemen "AturKost" yang digunakan oleh pemilik kost, pengelola kost dan penghuni kost. Flowchart diatas adalah gambaran tentang alur penggunaan sistem manajemen "AturKost" dimulai dari memasukkan kredensial pengguna sesuai dengan perannya 
masing-masing. Pengguna dapat memilih menu-menu yang mewakili fungsi dalam menampilkan dan memasukkan informasi yang ingin disampaikan kepada pengguna lain mulai dari menu komplain, layanan tambahan, pembayaran, serta pengumuman. Pemilik dan pengelola kost juga memiliki menu tambahan yaitu data penghuni. Pengguna akan memasukkan informasi yang kemudian akan ditampilkan pada halaman masing-masing penggunanya. Setelah selesai menggunakan sistem, pengguna dapat memilih tombol logout untuk mengakhiri proses penggunaan sistem manajemen "AturKost"

\section{b) Entity Relationship Diagram (ERD)}

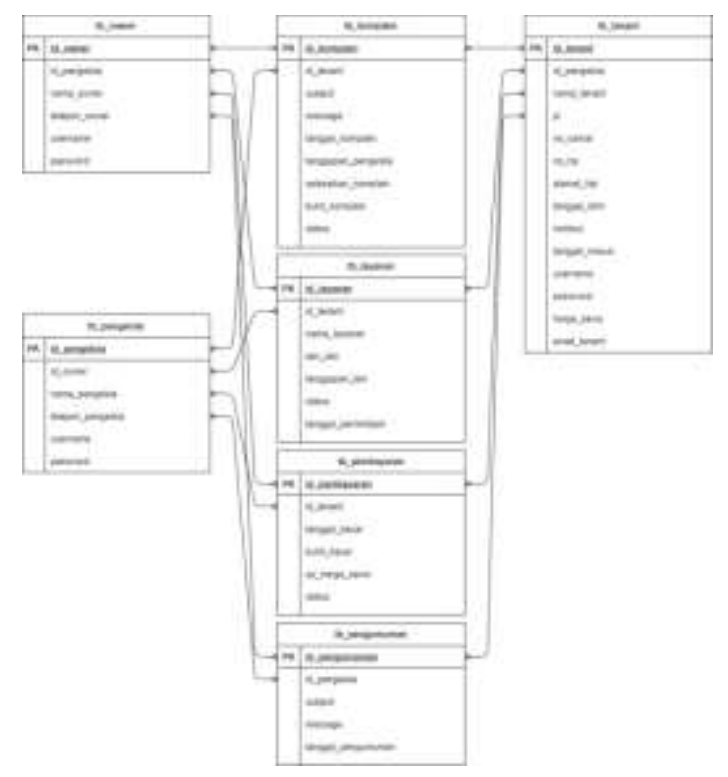

Gambar 2. ERD

Gambar 2 merupakan Entity Relationship Diagram (ERD) untuk sistem manajemen "AturKost". Diagram tersebut menunjukkan ada tiga entitas pengguna yaitu tb_owner (aktor pemilik kost), tb_pengelola (aktor pengelola kost), dan tb_tenant (aktor penghuni kost). Ketiga entitas ini terhubung dengan empat entitas fungsi yaitu tb_komplain (menu komplain), tb_layanan (menu layanan tambahan), tb_pembayaran (menu pembayaran), dan tb_pengumuman (menu pengumuman). Setiap entitas tersebut memiliki hubungan many-to-many karena semua entitas tersebut saling berhubungan satu sama lain dan setiap aktivitas yang terjadi akan mempengaruhi setiap informasi data. Hal ini membuat jika ada seorang pengguna yang menggunakan sistem dan merubah informasi, maka perubahan itu akan dapat langsung dilihat oleh semua peengguna.

\section{c) Use Case Diagram}

Use case diagram digunakan untuk mendeskripsikan sebuah interaksi antara satu atau lebih aktor dengan sistem yang akan dibuat. Use case diagram juga dapat digunakan untuk mengetahui fungsi apa saja yang ada di dalam sebuah sistem dan bisa juga mempresentasikan sebuah interaksi aktor dengan sistem. Use case diagram untuk sistem manajemen "AturKost" dapat dilihat pada gambar berikut:

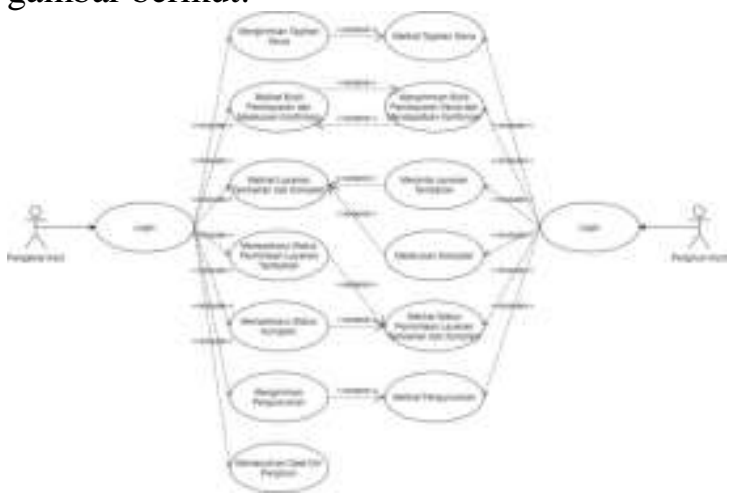

Gambar 3. Use Case

Pada gambar 3 dapat dilihat bahwa ada dua aktor yang berperan sebagai pengelola kost dan penghuni kost. Penghuni kost dapat melihat tagihan sewa kost pada bulan itu, memasukkan bukti pembayaran kedalam sistem, dan melihat status konfirmasi pembayaran tersebut. Penghuni kost juga dapat meminta layanan tambahan seperti televisi, pemanas air, laundry, dan sebagainya. Pada sistem ini penghuni kost juga dapat menyuarakan keluhan mereka kepada pengelola kost mengenai kerusakan maupun kondisi kamar. Penghuni kost dapat melihat status permintaan layanan tambahan dan juga tanggapan keluhan pada sistem ini. Pengumuman yang diinfokan oleh pengelola kost juga dapat dilihat langsung melalui sistem ini. Beralih kepada penggunaan oleh pengelola kost, mereka dapat mengirimkan tagihan sewa kost, melihat bukti pembayaran yang dimasukkan oleh penghuni kost, serta mengirimkan kembali status konfirmasi pembayaran sewa kepada penghuni kost. Pengelola kost dapat melihat keluhan yang disampaikan oleh penghuni kost dan juga permintaan tambahan yang diajukan oleh 
mereka. Setelah itu pengelola dapat menginformasikan status keluhan dan permintaan layanan tersebut melalui sistem "AturKost" sehingga penghuni kost dapat mengetahui apakah permintaan dan keluhan mereka sudah ditanggapi oleh pengelola kost. Jika ada pengumuman yang hendak disampaikan oleh pengelola kost kepada penghuni kost, pengelola kost dapat mengirimkannya melalui sistem "AturKost" dan akan diterima oleh penghuni kost. Tidak ketinggalan juga bahwa pengelola kost dapat memasukkan data diri penghuni kost. Pada sistem manajemen "AturKost", pengelola kost hanya bisa memberikan tanggapan dan bukti tindakan pada menu komplain, layanan tambahan, dan pembayaran. Pengelola kost dengan akun pemilik kost saja yang dapat merubah status dari setiap aktivitas yang terjadi. Hal ini bertujuan untuk mencegah adanya kecurangan yang dilakukan oleh pengelola kost.

\section{d) Activity Diagram}

Activity diagram memperlihatkan urutan aktifitas proses pada sistem untuk membantu memahami proses secara keseluruhan. Activity diagram dibuat berdasarkan sebuah atau beberapa use case. Activity diagram untuk sistem manajemen "AturKost" dapat dilihat pada penjelasan selanjutnya.

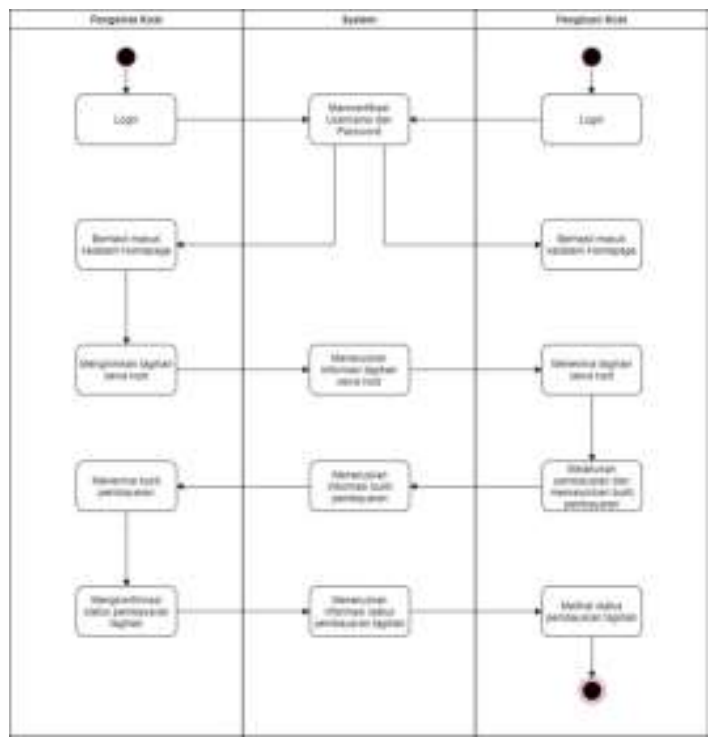

Gambar 4. Activity Diagram Pembayaran

Gambar 4 merupakan activity diagram untuk menunjukkan proses penyampaian informasi mengenai pembayaran. Pengelola kost dan penghuni kost melakukan login dan sistem akan melakukan verifikasi berdasarkan username dan password pengguna. Setelah itu sistem akan menampilkan homepage kepada pengguna. Proses pertama dilakukan oleh pengelola kost dimana pengelola kost akan memasukkan tagihan sewa kedalam sistem dan sistem akan meneruskan informasi tersebut kepada penghuni kost. Setelah penghuni kost melihat tagihan tersebut, penghuni akan melakukan pembayaran dengan cara transfer bank dan bukti pembayaran tersebut harus diupload melalui sistem. Bukti pembayaran tersebut akan diteruskan kepada pengelola kost agar dapat mengkonfirmasi status pembayaran tagihan tersebut dan disampaikan kepada penghuni kost. Tentu saja pengelola kost yang dapat mengkonfirmasi status pembayaran adalah yang menggunakan akun pemilik kost.

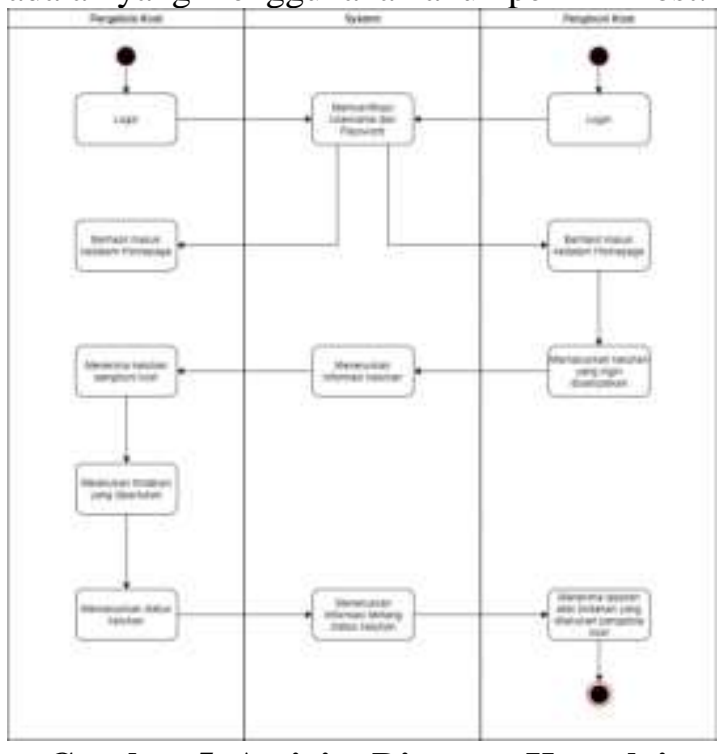

Gambar 5. Activity Diagram Komplain

Gambar 5 merupakan activity diagram komplain yang menunjukkan proses penghuni kost dalam menyampaikan keluhan dan tanggapan dari pihak pengelola kost. Penghuni memasukkan keluhan yang ingin disampaikan kedalam sistem dan kemudian informasi tersebut diteruskan kepada pengelola kost. Pengelola kost akan melakukan tindakan yang dibutuhkan. Jika sudah selesai ditangani, pengelola kost akan melakukan konfirmasi atas status keluhan tersebut agar penghuni kost mengetahui tindakan apa yang sudah dilakukan oleh pengelola kost. 


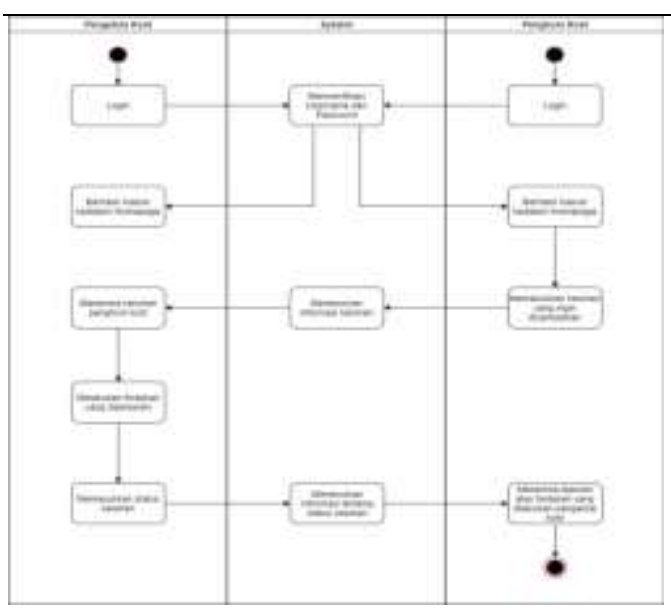

Gambar 6. Activity Diagram Layanan Tambahan

Gambar 6 merupakan activity diagram yang menjelaskan proses penghuni kost dalam meminta layanan tambahan kepada pengelola. Penghuni kost akan login kedalam sistem dan memilih menu permintaan layanan tambahan. Setelah itu penghuni kost bisa memilih layanan tambahan apa yang diinginkan dan kemudian informasi itu akan diteruskan kepada pengelola kost. Pengelola kost akan melakukan tindakan yang diperlukan sesuai dengan permintaan penghuni kost dan memberikan update mengenai status permintaan layanan tambahan. Penghuni kost dapat melihat status permintaan layanan tambahan tersebut pada sistem.

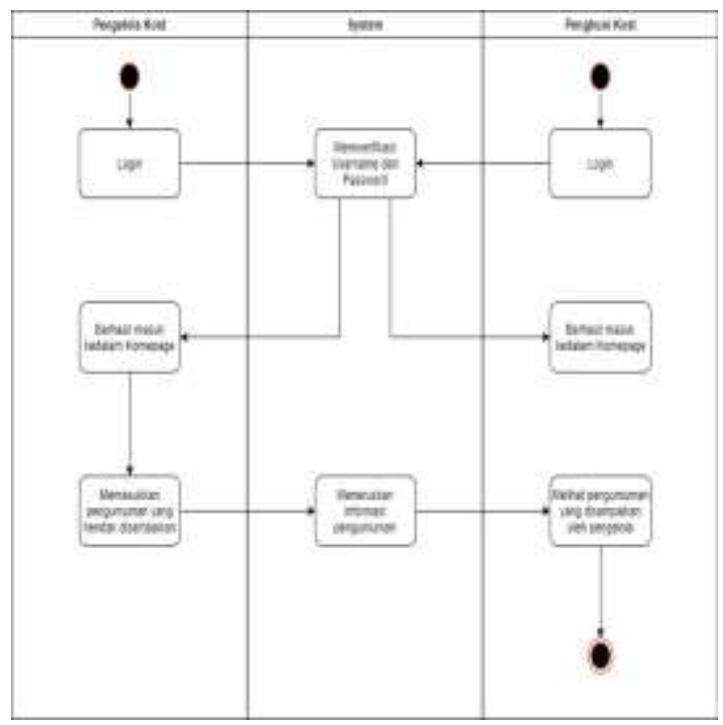

\section{Gambar 7. Activity Diagram Pengumuman}

Gambar 7 merupakan activity diagram pengumuman yang menjelaskan tentang proses pemberitahuan pengumuman dari pengelola kost kepada penghuni kost. Pengelola kost memasukkan kedalam sistem pengumuman yang ingin disampaikan kepada penghuni kost. Informasi tersebut akan diteruskan oleh sistem dan hasilnya dapat dilihat oleh penghuni kost.

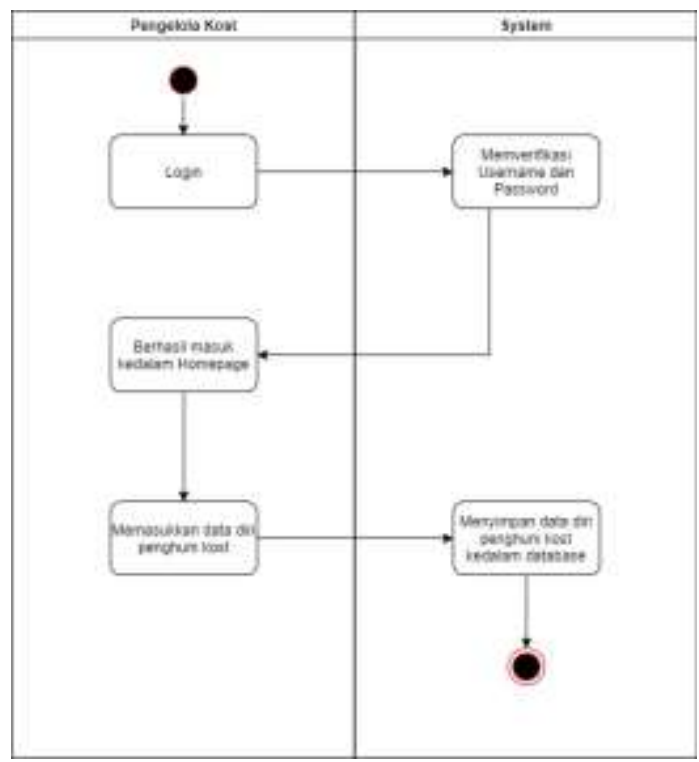

\section{Gambar 8. Acitivity Diagram Tambah Penghuni}

Gambar 8 merupakan activity diagram data diri penghuni kost dimana diagram ini menjelaskan tentang proses penghuni kost dalam memasukkan data diri penghuni yang telah dicatat pada saat pendaftaran. Penghuni kost hanya perlu login kedalam sistem manajemen "AturKost" dan kemudian memilih fungsi menambahkan data diri penghuni kost. Setelah data berhasil dimasukkan, data tersebut akan disimpan didalam database server.

\section{Hasil Rancangan Tampilan}

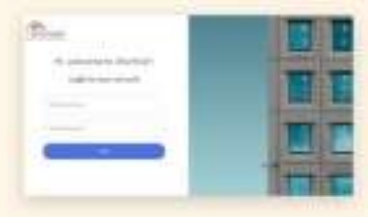

Gambar 9. Halaman Login 
Gambar 9 adalah halaman login untuk penghuni kost, pengelola kost, dan pemilik kost. Pengguna perlu memasukkan username dan password masing-masing dan kemudian sistem akan secara otomatis memverifikasi peran pengguna tersebut dan dilanjutkan ke halaman beranda penghuni, pemilik, atau pengelola kost.

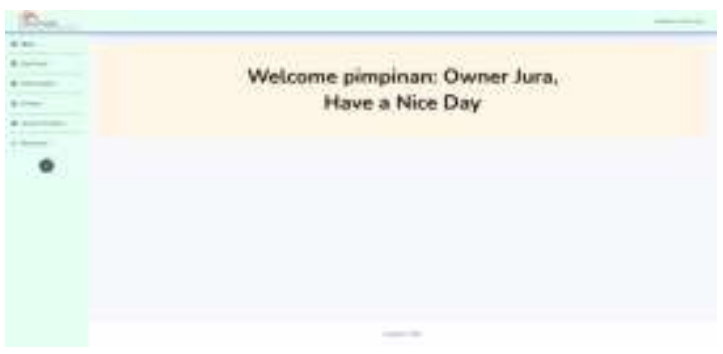

\section{Gambar 10. Halaman Beranda - Pemilik}

Gambar 10 merupakan halaman beranda yang ditampilkan ketika pengguna memasukkan username dan password pemilik kost. Terdapat lima fungsi yang dapat digunakan oleh pengelola kost yaitu menu data tenant, data pengelola, komplain, layanan tambahan, dan pembayaran.

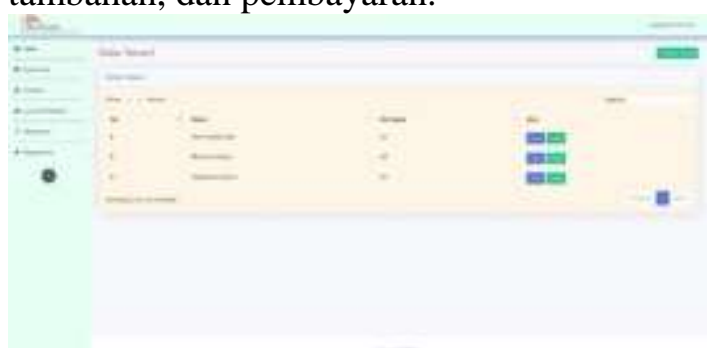

\section{Gambar 11. Halaman Data Tenant}

Gambar 11 adalah halaman yang ditampilkan ketika pengelola kost memilih menu data tenant. Halaman ini menampilkan nama-nama penghuni kost dan nomor kamar. Terdapat tombol view dan tambah tenant.

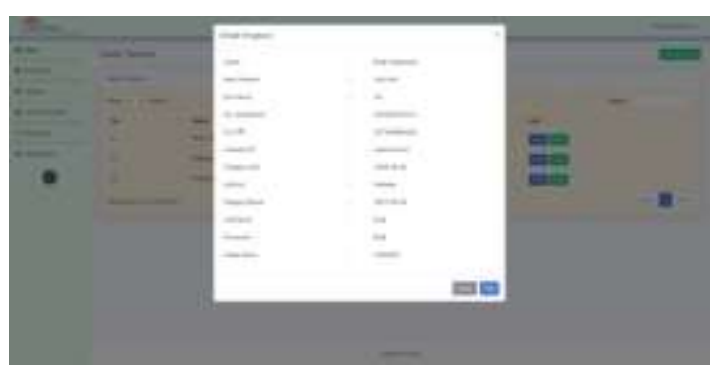

Gambar 12. Halaman Detil Penghuni Kost
Gambar 12 adalah halaman yang ditampilkan pada saat pengelola kost memilih tombol view. Halaman ini menampilkan data detil penghuni kost. Pengelola kost juga dapat memilih tombol edit. Data yang ditampilkan adalah nama, jenis kelamin, nomor kamar, nomor handphone, nomor KTP, alamat KTP, tanggal lahir, institusi, tanggal masuk, username, password, harga sewa, dan alamat email.

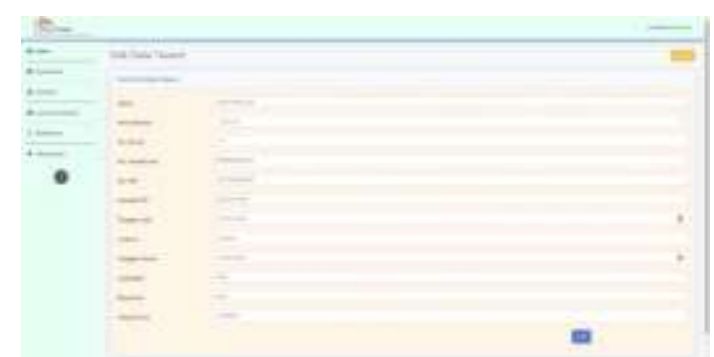

\section{Gambar 13. Halaman Edit Data Penghuni Kost}

Gambar 13 adalah halaman yang ditampilkan pada saat pengelola memilih tombol edit pada halaman sebelumnya. Halaman ini menampilkan form detil data penghuni kost yang dapat diubah oleh pengelola kost. Jika data yang diubah sudah benar, pengelola kost dapat memilih tombol edit kembali untuk menyimpan data terbaru.

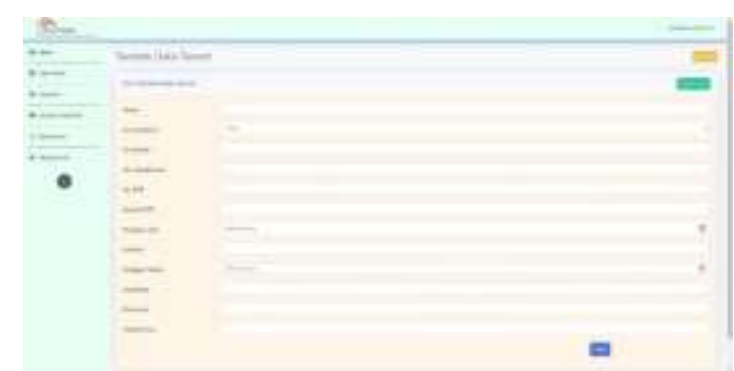

Gambar 14. Halaman Tambah Penghuni Kost

Gambar 14 adalah halaman yang ditampilkan pada saat pengelola kost memilih tombol tambah tenant. Halaman ini menampilkan form yang sama seperti edit detil penghuni kost tetapi masih belum terisi. Pengelola kost dapat memasukkan data detil penghuni kost dan kemudian memilih tombol add untuk menyimpan data. 


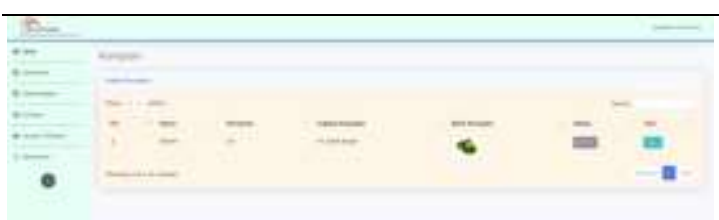

Gambar 15. Halaman Pemilik - Komplain

Gambar 15 adalah halaman yang ditampilkan pada saat pemilik kost memilih menu komplain. Halaman ini menampilkan daftar komplain yang disampaikan oleh penghuni kost. Informasi yang ditampilkan adalah nama penghuni, nomor kamar, subyek komplain, dan status komplain. Terdapat juga bukti pengerjaan komplain yang telah dilakukan oleh pengelola kost sehingga pemilik kost dapat menentukan apakah komplain tersebut sudah diatasi atau belum. Jika sudah sesuai, pemilik kost dapat memilih tombol "SET OK" untuk merubah status komplain menjadi "Done". Pemilik kost dapat memilih tombol view untuk melihat detil komplain.

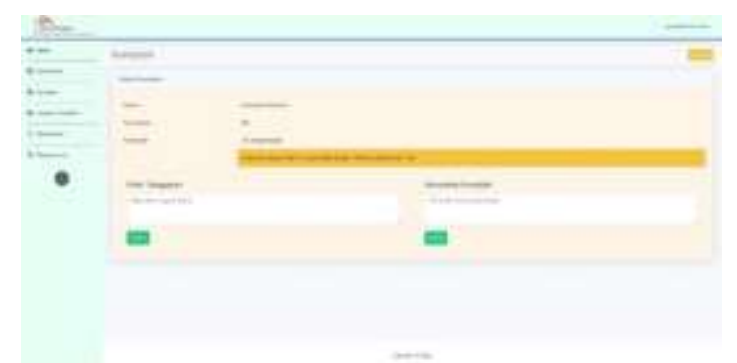

\section{Gambar 16. Halaman Detil Komplain}

Gambar 16 adalah halaman yang ditampilkan pada saat pengelola kost memilih tombol view pada halaman sebelumnya. Halaman ini menampilkan detil komplain yang disampaikan oleh penghuni kost. Pengelola kost dapat memberikan tanggapan dan juga menyelesaikan komplain jika permasalahan tersebut sudah teratasi.

\section{Gambar 17. Halaman Pengelola Kost - Layanan Tambahan}

Gambar 17 adalah halaman yang ditampilkan pada saat pengelola kost memilih menu layanan tambahan. Halaman ini menampilkan informasi nama penghuni, nomor kamar, subyek layanan tambahan, dan status layanan tambahan. Pengelola kost juga dapat memilih tombol view untuk melihat detil permintaan layanan tambahan dan juga status tindakan yang dilakukan. Status OK berarti permintaan tersebut telah dipenuhi, status NO berarti belum diproses, status REJECT berarti permintaan tersebut ditolak.

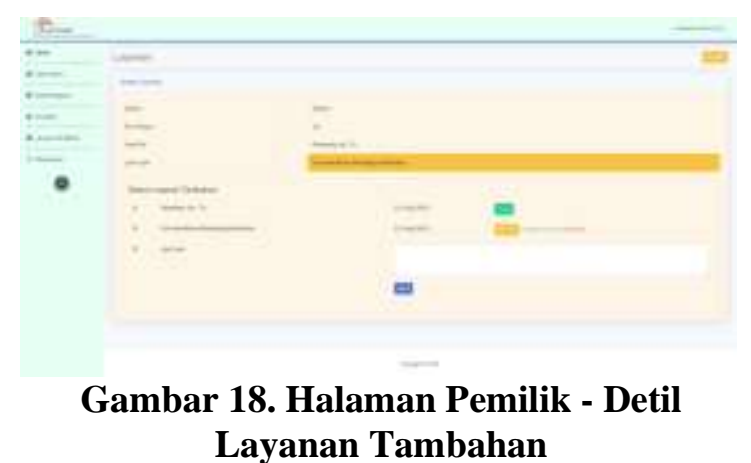

Gambar 18 adalah halaman yang ditampilkan pada saat pemilik kost memilih tombol view pada halaman sebelumnya. Halaman ini menampilkan detil permintaan tambahan yang diajukan penghuni kost. Pemilik kost dapat memilih tombol change to done jika layanan yang diminta sudah terpenuhi atau memilih tombol reject jika tidak dapat menyediakan permintaan penghuni kost. Untuk halaman detil layanan tambahan pengelola kost tidak disediakan tombol perubahan status ini karena tombol ini hanya bisa dipilih oleh pemilik kost. 


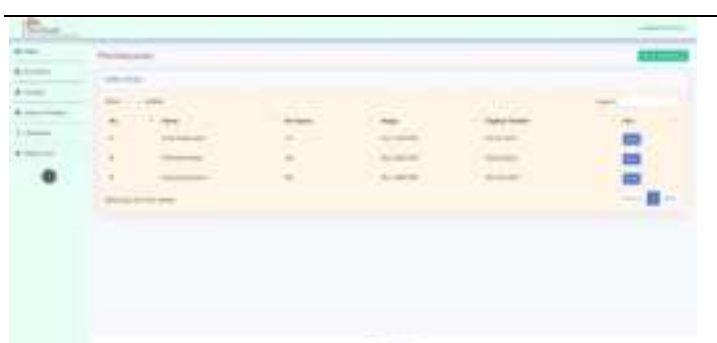

Gambar 19. Halaman Pengelola Pembayaran

Gambar 19 adalah halaman yang ditampilkan ketika pengelola kost memilih menu pembayaran. Halam ini menampilkan informasi nama penghuni, nomor kamar, harga sewa dan tagihan yang terakhir dikirim. Pengelola kost dapat mengirimkan tagihan pembayaran kepada penghuni kost dengan memilih tombol send dan melihat status pembayaran dengan memilih tombol status pembayaran.

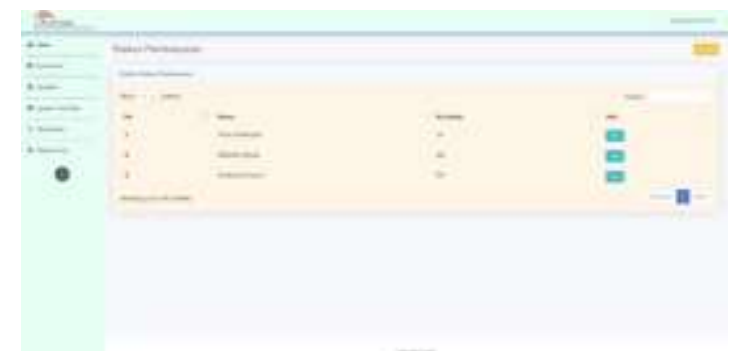

\section{Gambar 20. Halaman Status Pembayaran}

Gambar 20 adalah halaman yang ditampilkan pada saat pengelola kost memilih tombol status pembayaran di halaman sebelumnya. Pengelola kost dapat status pembayaran tiap penghuni kost dengan memilih tombol view.

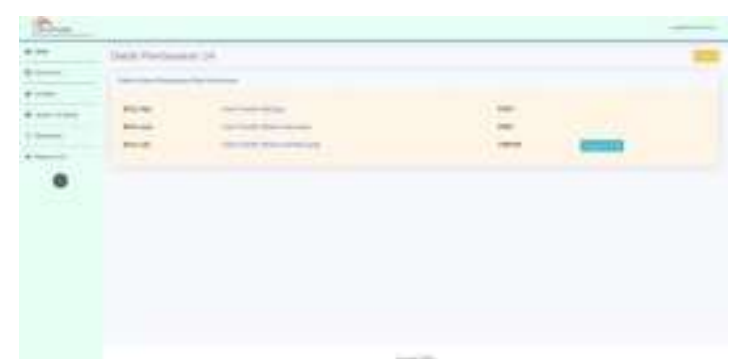

\section{Gambar 21. Halaman Detil Status Pembayaran}

Gambar 21 adalah halaman yang ditampilkan pada saat pengelola kost memilih tombol view pada halaman sebelumnya. Halaman ini menampilkan riwayat pembayaran penghuni kost. Penghuni kost dapat melihat bukti pembayaran yang dimasukkan oleh penghuni kost dan mengkonfirmasi pembayaran tersebut dengan memilih tombol change to paid. Setelah status pembayaran dikonfirmasi oleh pemilik kost, maka pengelola kost dapat mengirimkan tagihan selanjutnya kepada penghuni kost sesuai dengan periode pembayaran.

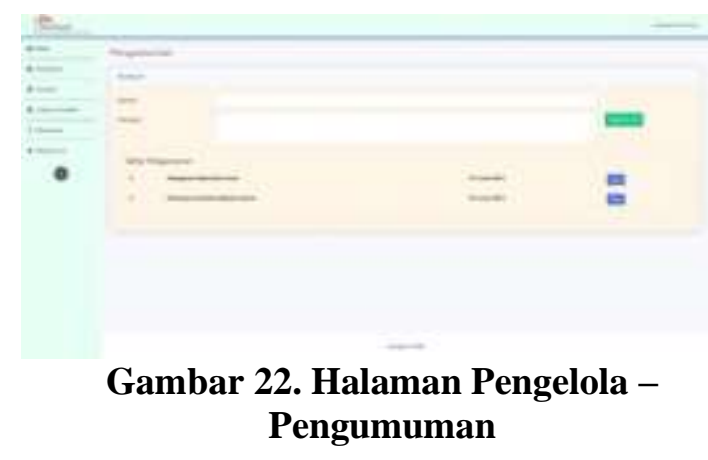

Gambar 22 adalah halaman yang ditampilkan pada saat pengelola kost memilih menu pengumuman. Halaman ini menampilkan daftar pengumuman yang pernah dikirimkan kepada penghuni kost. Pengelola kost dapat memilih tombol view untuk melihat detil pengumuman tersebut. Jika pengelola kost ingin mengirimkan pengumuman kepada seluruh penghuni, maka pengelola kost dapat memasukkan pengumuman tersebut di kolom subject dan message dan kemudian memilih tombol send to all. Setelah pengelola kost mengirimkan pengumuman melalui sistem manajemen "AturKost", maka sistem juga akan otomatis mengirimkan pengumuman tersebut ke email penghuni kost yang terdaftar pada data tenant.

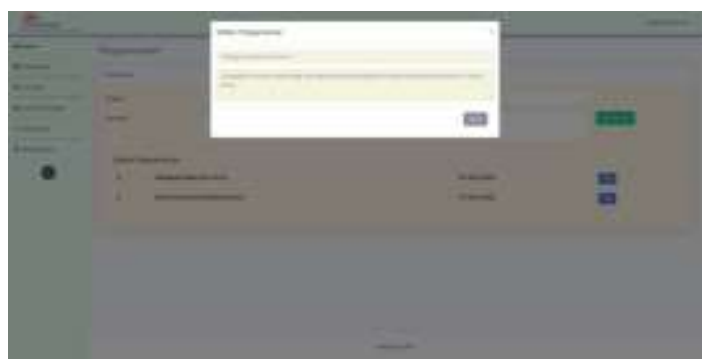

Gambar 23. Halaman Detil Pengumuman Pengelola

Gambar 23 adalah halaman yang ditampilkan pada saat pengelola kost memilih tombol view pada halaman sebelumnya. Halaman ini menampilkan isi detil dari 
Versi Online: http://journal.ubm.ac.id/index.php/jbase DOI: http://dx.doi.org/10.30813/jbase.v4i2.3003 Hasil Penelitian

pengumuman berdasarkan subyek yang dipilih.

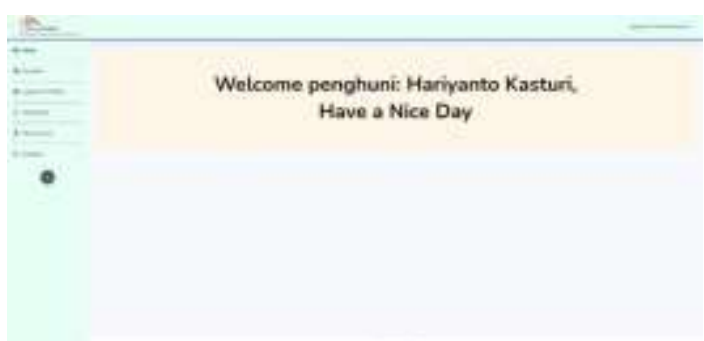

\section{Gambar 24. Halaman Beranda Penghuni}

Gambar 24 adalah halaman yang ditampilkan ketika pengguna memasukkan username dan password sebagai penghuni kost. Halaman ini menampilkan menu-menu yang dapat dipilih oleh penghuni kost yaitu komplain, layanan tambahan, pembayaran, pengumuman, dan checkout.

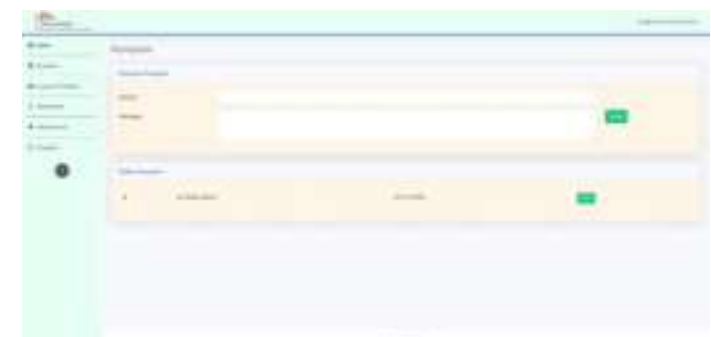

\section{Gambar 25. Halaman Penghuni - Komplain}

Gambar 25 adalah halaman yang ditampilkan pada saat penghuni kost memilih menu komplain. Halaman ini menampilkan daftar komplain yang pernah disampaikan kepada pengelola dan penghuni dapat memilih tombol view untuk melihat tanggapan pengelola. Jika ingin menyampaikan komplain, penghuni dapat memasukkannya di kolom subject dan message, lalu memilih tombol send.

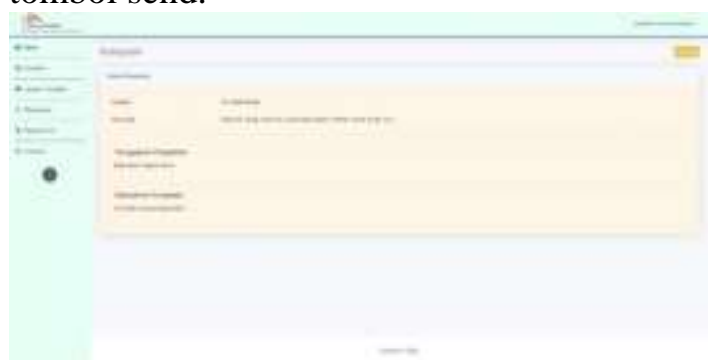

Gambar 26. Halaman Tanggapan Komplain

Gambar 26 adalah halaman yang ditampilkan pada saat penghuni kost memilih
Journal of Business and Audit Information Systems

Vol 4 (No.2) : 41-56. 2021

p-ISSN: 2615-6431

e-ISSN: 2620-7907

tombol view pada halaman sebelumnya. Halaman ini menampilkan informasi komplain yang kita sampaikan, tanggapan pengelola, dan tindakan yang telah dilakukan.

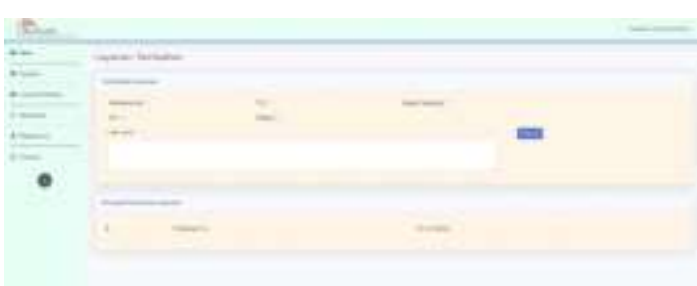

\section{Gambar 27. Halaman Penghuni - Layanan Tambahan}

Gambar 27 adalah halaman yang ditampilkan pada saat penghuni kost memilih menu layanan tambahan. Penghuni kost dapat memilih layanan tambahan yang diinginkan dan kemudian memilih tombol request. Jika ada permintaan yang tidak tersedia di kotak pilihan, penghuni kost dapat menuliskannya di kolom lain-lain.

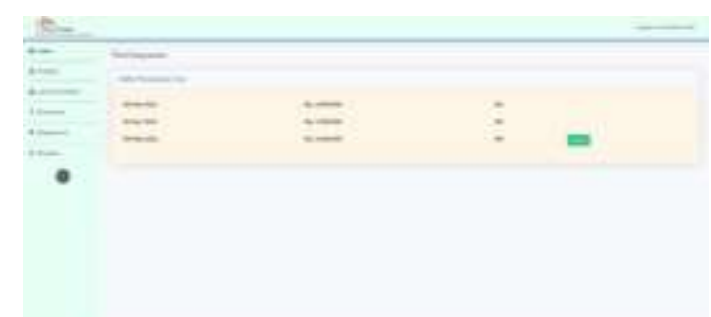

\section{Gambar 28. Halaman Penghuni - Pembayaran}

Gambar 28 adalah halaman yang ditampilkan pada saat penghuni kost memilih menu pembayaran. Halaman ini menampilkan riwayat pembayaran dan tagihan yang belum dibayarkan, termasuk status pembayaran. Penghuni kost dapat memilih tombol submit untuk memasukkan bukti transfer.

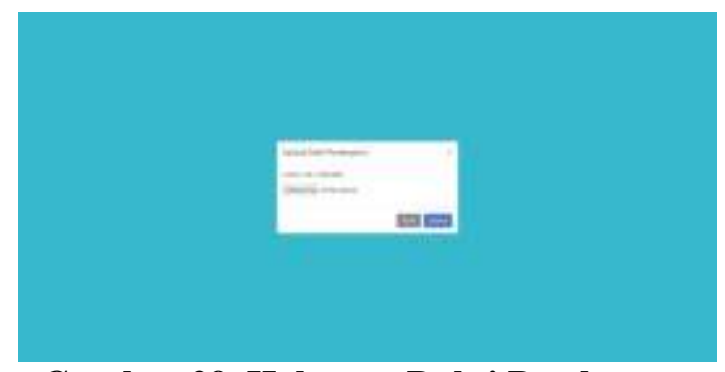

Gambar 29. Halaman Bukti Pembayaran 
Gambar 29 adalah halaman yang ditampilkan pada saat penghuni kost memilih tombol submit pada halaman sebelumnya. Pada halaman ini penghuni kost dapat mememasukkan bukti transfer dan kemudian memilih tombol upload.

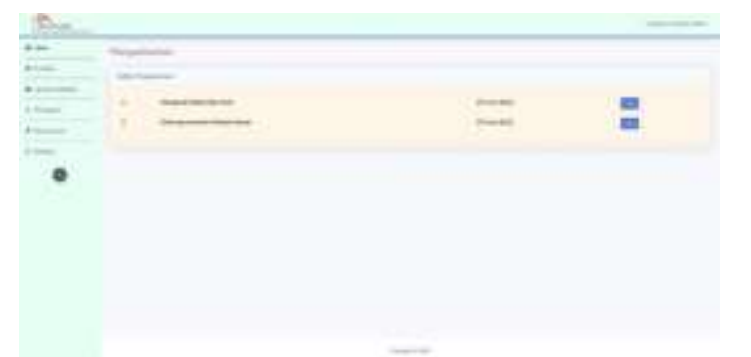

\section{Gambar 30. Halaman Penghuni - Pengumuman}

Gambar 30 adalah halaman yang ditampilkan pada saat penghuni kost memilih menu pengumuman. Halaman ini menampilkan daftar pengumuman yang dikirimkan pengelola kost dan penghuni kost dapat melihat isi detil pengumuman tersebut dengan memilih tombol view. Halaman ini juga menampilkan tanggal dikirimnya tiap pengumuman.

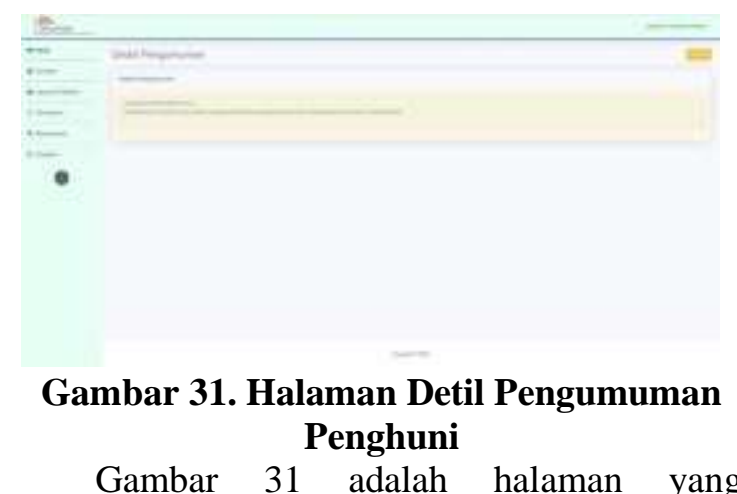
ditampilkan pada saat penghuni kost memilih tombol view pada halaman sebelumnya. Halaman ini menampilkan detil pengumuman yang disampaikan pengelola kost.

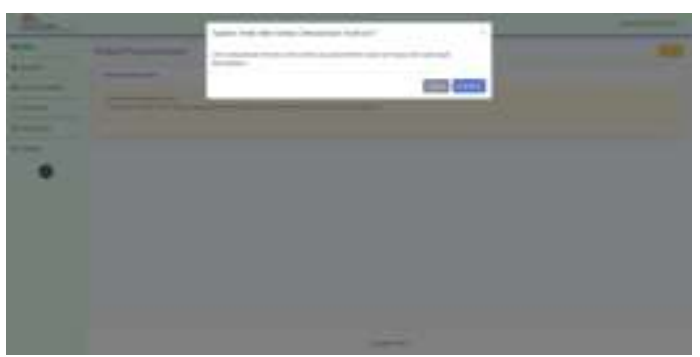

Gambar 32. Halaman Penghuni - Checkout
Gambar 32 adalah halaman yang ditampilkan pada saat penghuni kost memilih menu checkout. Jika penghuni kost memilih tombol checkout, maka penghuni kost tidak dapat lagi mengakses sistem manajemen "AturKost" dan data penghuni kost akan dihapus dari basis data.

\section{SIMPULAN}

Berdasarkan hasil perancangan sistem manajemen "AturKost" yang telah dibangun, dapat ditarik kesimpulan sebagai berikut:

1. Telah dibuat sistem manajemen kost bernama "AturKost" yang dapat memfasilitasi setiap pencatatan aktifitas yang terjadi pada gedung kost. Pengelola kost juga dapat melihat data penghuni, komplain, permintaan layanan tambahan, dan pembayaran yang terjadi pada gedung kost. Penghuni kost juga dapat mengirimkan pengumuman langsung yang dapat dilihat oleh penghuni kost. Hanya pemilik kost yang dapat merubah status komplain, layanan tambahan, dan pembayaran untuk menghindari kecurangan yang dilakukan oleh pengelola kost.

2. Rancangan pada sistem manajemen "AturKost" dibuat secara sederhana dengan hanya menampilkan fungsi-fungsi yang diperlukan saja. Tampilan pada "AturKost" tidak menggunakan ikon karena dapat membuat kebingungan pada penggunanya. Karena itu digunakan teks dan tombol sederhana yang mempermudah penggunaannya.

3. Penghuni kost dapat dengan mudah berinteraksi dengan pengelola kost dengan memilih menu yang tersedia pada halaman sistem. Fungsi yang disediakan saat ini terkait dengan komplain, permintaan layanan tambahan, pembayaran, dan juga pengumuman.

\section{DAFTAR PUSTAKA}

Asmanto, B., Mustika, \& Tria, A. (2020). Implementasi Metode SDLC Pada Aplikasi Pengolahan Data Laporan Bulanan Kegiatan Puskesmas. Jsai, 3(1).

Bilqis, L. D. R., (2018). Analisis Faktor Pemilihan Kos-Kosan Menggunakan 
Mendirikan Usaha. Pengabdian Dan

Kewirausahaan, 2(1), 29-37.

https://journal.ubm.ac.id/index.php/peng

abdian-dan

kewirausahaan/article/view/1131

Budio, S. (2019). Manajemen Data Base. Menata, 2(1).

Firman, A., Wowor, H. F., Najoan, X., Teknik, J., Fakultas, E., \& Unsrat, T. (2016). Sistem Informasi Perpustakaan Online Berbasis Web. E-Journal Teknik Elektro Dan Komputer, 5(2), 29-36.

Hendini, A. (2016). Pemodelan Uml Sistem Informasi Monitoring Penjualan Dan Stok Barang Barang (Studi Kasus: Distro Zhezha Pontianak). Jurnal Khatulistiwa Informatika, IV(2), 107-116. Retrieved from

https://ejournal.bsi.ac.id/ejurnal/index.ph p/khatulistiwa/article/viewFile/1262/102 7

Irawan, A., Risa, M., Muttaqien, M. A., \& Shinnay, A. E. (2017). Perancangan Sistem Informasi Penjualan Pakaian Pada $\mathrm{Cv}$ Nonninth Inc Berbasis Online. POSITIF : Jurnal Sistem Dan Teknologi Informasi, https://doi.org/10.31961/positif.v3i2.417

Risdiansyah, D. (2017). Perancangan Sistem Informasi Bimbingan Konseling Berbasis Desktop pada SMA Kemala Bhayangkari 1 Kubu Raya Deni. Khatulistiwa Informatika, $V(2), 86-91$.

Syam, E. (2018). Rancang Bangun Sistem Informasi Rumah Kost Dan Kontrakan Teluk Kuantan. Jurnal Teknologi Dan Open Source, 1(1), 1-7. https://doi.org/10.36378/jtos.v1i1.2

Wijianto, R., Anggoro, A., Informasi, S., \& Informatika, M. (2018). Sistem Informasi Pendaftaran Seleksi Kerja Berbasis Web Pada Bkk (Bursa Kerja Khusus) Tunas Insan Karya Smk Negeri 2, 6(1), 76-84.

Yulianto, S. V., \& Atmaja, A. P. (2018). Rancang Bangun Sistem Informasi Kurikulum 2013 Tingkat Sekolah Dasar Berbasis Web dengan SDLC Waterfall. Sisfo, $07(02)$. https://doi.org/10.24089/j.sisfo.2018.01. 006 